\title{
ON TWO METHODS TO ESTIMATE PRODUCTION OF Eichhornia crassipes IN THE EUTROPHIC PAMPULHA RESERVOIR (MG, BRAZIL)
}

\author{
GRECO, M. K. B. ${ }^{1}$ and FREITAS, J. R. de ${ }^{2}$ \\ ${ }^{1}$ Ecologia, Conservação e Manejo de Vida Silvestre, Departamento de Biologia Geral, Instituto de \\ Ciências Biológicas, Universidade Federal de Minas Gerais, CEP 31270-901, Belo Horizonte, MG, Brazil \\ ${ }^{2}$ Departamento de Biologia Geral, Instituto de Ciências Biológicas, Universidade Federal de Minas Gerais, \\ CEP 31270-901, Belo Horizonte, MG, Brazil \\ Correspondence to: Magda Karla Barcelos Greco, Departamento de Biologia Geral, \\ Instituto de Ciências Biológicas, Universidade Federal de Minas Gerais, \\ CEP 31270-901, Belo Horizonte, Minas Gerais, Brazil, e-mail: greco@icb.ufmg.br \\ Received August 14, 2000 - Accepted December 11, 2000 - Distributed August 31, 2002
}

(With 2 figures)

\begin{abstract}
This paper deals with variations in biomass and in the production of Eichhornia crassipes (water hyacinth) in a eutrophic tropical reservoir. Net production was assessed by both a traditional method and a demographic approach. The initial biomass ranges from $96 \mathrm{~g} \mathrm{DW} \cdot \mathrm{m}^{-2}$ to a maximum of $2027 \mathrm{~g} \mathrm{DW} . \mathrm{m}^{-2}$. Net production estimates varied greatly according to which method was used to calculate them (traditional: 20.6 ton DW.hectare ${ }^{-1}$.year ${ }^{-1}$, demographic: 226.9 ton DW.year ${ }^{-1}$ ).
\end{abstract}

Key words: Eichhornia crassipes (water hyacinth), biomass production, modular demography, macrophytes.

\section{RESUMO}

\section{Sobre dois métodos para estimar a produção de Eichhornia crassipes no reservatório eutrófico Pampulha (MG, Brasil)}

Este estudo mostra as variações da biomassa e da produção de Eichhornia crassipes em um reservatório eutrófico tropical. A produção líquida foi estimada por intermédio do método tradicional e do demográfico. A biomassa inicial de $96 \mathrm{~g} \mathrm{PS} . \mathrm{m}^{-2}$ chegou ao máximo de $2.027 \mathrm{~g} \mathrm{PS} . \mathrm{m}^{-2}$ A produção líquida variou de acordo com o método utilizado para sua estimativa (tradicional: 20,6 ton PS. ha ${ }^{-1}$.ano ${ }^{-1}$, demográfico: 226,9 ton PS.ano ${ }^{-1}$ ).

Palavras-chave: Eichhornia crassipes (aguapé), produção de biomassa, macrófitas, método demográfico.

\section{INTRODUCTION}

Some macrophytes when introduced into new habitats, undergo a great demographic explosion, and so are regarded as weeds (Holm et al., 1969). Eichhornia crassipes (Mart.) Solms, one such species, is one of the main aquatic weeds in 52 different countries (NAS, 1981).

The high reproductive capacity and rapid growth of Eichhornia crassipes endow it with high vegetative development and productivity rates. These characteristics, along with an extreme tolerance, have given this macrophyte efficient mechanisms for reproduction and dispersion, rendering it able to form dense stands within a few months in a large variety of habitats, such as rivers, lakes, or reservoirs. This could be the result of the lack of predators, competitors, or natural endemic diseases, added to intrinsic characteristics of the species, or physical and chemical conditions of the habitat (Gopal, 1987).

The rapid growth of this species has resulted in alterations in many bodies of water, by increasing evapotranspiration, by making navigation impossible, and by bringing about a negative effect on recreation. Population explosions of these plants 
also cause an increase in appropriate sites for the development of mosquitoes and snails, which are vectors of several diseases, and deplete oxygen in the superficial levels of the water column, which can cause great plankton and fish mortality (NAS, 1981).

Many researches have evaluated using different methods biomass production of this species, both in the field and laboratory. These studies show that its production can range from 14 to $44 \mathrm{t}$ DW.ha ${ }^{-1}$.year ${ }^{-1}$ (see Gaudet, 1974). However, works carried out under natural conditions have not emphasized demographic approaches, which take into account classical analysis of growth and allow for flow in individuals and their constituting parts (McGraw \& Garbutt, 1990). Since this flow represents the cycling of nutrients and the input of organic matter into the water body, its determination is important in studies of the ecology of aquatic systems (Pinto-Coelho \& Greco, 1999).

This research aimed at measuring the net primary production of Eichhornia crassipes using both a traditional method and a demographic approach to determine the temporal variations in its growth rate according to the biomass variation and the number of ramets and leaves. Identification of factors influencing those rates (nutrients, environmental temperature, density) and determination of the leaf and ramet turnover in the population, as well as estimates of dry mass input in the ecosystem, were further goals of the study.

\section{STUDY SITE}

This study was undertaken at the Pampulha Reservoir, located in Belo Horizonte (Brazil). It is small, having a volume of 12 million $\mathrm{m}^{3}$ of water, an area of 260 hectares, a perimeter of $21 \mathrm{~km}$, a maximum depth of $16 \mathrm{~m}$, and has been considered eutrophic since 1984 (Giani, 1994). Among the main causes of its eutrophy is the dumping of domestic sewage from a population of about 200,000 inhabitants. In recent years an explosion has occurred in the growth of Eichhornia crassipes, which has become the dominant species in the reservoir.

\section{METHODS}

The temporal dynamics of E. crassipes was assessed in plants kept in five enclosures of $9.0 \mathrm{~m}^{2}$
( $3 \mathrm{~m} \times 3 \mathrm{~m}$ ), each made of nylon web. They were fixed in the sediment by means of wood sticks. E. crassipes ramets were transferred to each enclosure in April, 1994. Ramets were small, with leaves showing dilated petioles. Initial density in each enclosure was 17 ramet $\mathrm{m}^{-2}$. Density of ramets was evaluated during each sampling. Analyses were done from May/94 to June/95.

\section{Biomass production}

One out of the five enclosures was used for biomass production analysis. On each sampling date, three samples of plants were collected using a square of PVC tubes with an area of $0.50 \mathrm{~m} \mathrm{x}$ $0.50 \mathrm{~m}$, following Westlake (1965). The ramets were washed in running water to remove periphyton, macroinvertebrates, and attached organic and inorganic material. To determine the dry weight, ramets were separated, numbered, and dried in an oven at $70^{\circ} \mathrm{C}$ until constant weight was reached. Growth rate determination was according to the formula described by Radford (1967).

ABSOLUTE GROWTH RATE (AGR)

$$
\frac{W_{2}-W_{1}}{t_{2}-t_{1}}
$$

RELATIVE GROWTH RATE (RGR)

$$
\frac{\ln W_{2}-\ln W_{1}}{t_{2}-t_{1}}
$$

where: $W=$ mean plant biomass for a group of harvested plants, $t=$ time.

Annual biomass productivity was calculated through the sum of the monthly differences in dry weight. $\mathrm{m}^{-2}$. The figures were then converted into t.ha ${ }^{-1}$.year ${ }^{1}$.

\section{Demographic approach}

Four enclosures were used for ramet and leaf analysis turnover. A subsample of 38 ramets in each enclosure was marked with metal labels. All the leaves from these ramets were marked with PVAbased colored glue, in order to determine, between two samplings, the rates of leaf production and death. On each sampling date the numbers of functional leaves, senescent or dead leaves, and remaining leaves were determined. Each new ramet produced was identified by a label, and submitted to the same procedure. 
The determination of relative growth rate for demographical growth was determined according to the procedure described by McGraw \& Garbutt (1990).

DEMOGRAPHIC RELATIVE GROWTH RATE (DRGR)

$\frac{\ln \eta_{2}-\ln \eta_{1}}{t_{2}-t_{1}}$

where: $\eta=$ number of modules, $t=$ time.

Productivity estimation by means of demographical analysis was done according to the equation:

$\mathrm{DW}_{\mathrm{i}}=\Sigma \mathrm{P}_{\mathrm{i}} \cdot \mathrm{X}_{\mathrm{i}}$

and the variation of $\mathrm{DW}_{\mathrm{i}}=\sum \frac{(P i)^{2}}{n i} \cdot S i^{2}$

where: $\mathrm{DW}_{\mathrm{i}}=$ biomass production (dry weight), $P_{i}=$ number of ramets (or leaves) lost per collection, $\mathrm{X}_{\mathrm{i}}=$ dry weight (of leaves or ramets) average per collection, $s_{i}=$ dry weight standard deviation per collection, $n_{i}=$ number of ramets (or leaves) sampled. The confidence interval of $95 \%$ for biomass production is equal to: $\mathrm{CI}^{95 \%}=\left\{\mathrm{DW}_{\mathrm{i}}-2\left[\operatorname{var}\left(\mathrm{DW}_{\mathrm{i}}\right)\right]^{1 / 2}\right.$; $\left.\mathrm{DW}_{\mathrm{i}}+2\left[\operatorname{var}\left(\mathrm{DW}_{\mathrm{i}}\right)\right]^{1 / 2}\right\}$.

The data for density; physical, and chemical variables in the water; and the air temperature were correlated with the growth rates. Pearson's correlation was used, except for the data without normal distribution, when Sperman's correlation $\left(\mathrm{r}_{\mathrm{s}}\right)$ was used, following Siegel (1975).

On each sampling date the water temperature, electrical conductivity, and $\mathrm{pH}$ were determined. Total amount of phosphorus and nitrogen were evaluated according to the method of Murphy \& Riley (1962) and Nessler (Greenberg et al., 1992), respectively. Monthly data for air temperature were obtained from the 5th Meteorological District, of the Ministry of Agriculture, Belo Horizonte, MG.

\section{RESULTS}

Meteorological, physical, and chemical variables

The period from June to August/1994 was caracterized by low values in average air temperature; the highest values were registered from December/1994 to February/1995 (Table 1). Water temperature oscillated between $18.0^{\circ} \mathrm{C}$ (July/1994) and $29.0^{\circ} \mathrm{C}$ (December/1994). The
pH ranged from 6.9 (January/1994) to 8.8 (December/1994) (Table 1). The electrical conductivity showed the highest values in the dry months, mainly in September and October of $1994\left(301 \mu \mathrm{S} . \mathrm{cm}^{-1}\right.$ and $304 \mu \mathrm{S} . \mathrm{cm}^{-1}$, respectively); the lowest value was in March/1995 (183.7 $\mu$ S.cm ${ }^{-1}$ ) (Table 1).

Total phosphorus concentration varied from 0.03 mg. $\mathrm{l}^{-1}$ (June/1994) to $1.59 \mathrm{mg} . \mathrm{l}^{-1}$ (September/1994), with an average concentration of $0.48 \mathrm{mg} . \mathrm{l}^{-1}$ (SD \pm 0.44) (Table 1). Total nitrogen concentration varied considerably throughout the experimental period. Average concentration was $4.47 \mathrm{mg} . \mathrm{L}^{-1}(\mathrm{SD} \pm 2.66)$ for all sampled months (Table 1).

\section{Density and biomass production}

The lowest ramet density was registered in September/1994 with 65 ramets. $\mathrm{m}^{-2}$, and the highest in December/1994, with 156 ramets. ${ }^{-2}$ (Fig. 1). After November/1994, all subdivisions of the nylon frame were completely occupied.

The study period was characterized by a phase of low biomass values, from May/1994 until November/1994, and another of high biomass values, from December/1994 until June/1995. Total initial biomass was $96 \mathrm{~g}$ of DW.m ${ }^{-2}$. This value almost doubled in a month, increasing to $167 \mathrm{~g}$ of DW.m $\mathrm{m}^{-2}$. It increased continuously until July/1994, and then declined until September/1994. Biomass growth reached $2027 \mathrm{~g}$ of DW.m ${ }^{-2}$ in January/95 (Table 2). Production, calculated through the sum of the monthly biomass differences, was $20.6 \mathrm{t}$ of DW.ha ${ }^{-1}$.year ${ }^{-1}$.

The highest growth rate was registered in January/1995, $22.17 \mathrm{~g}$ of DW.m ${ }^{-2} \cdot \mathrm{d}^{-1}$. Negative values for absolute growth rate were found in certain periods, but the biggest loss was registered in March/ $1995,-5.58 \mathrm{~g}$ of DW. $\mathrm{m}^{-2} \cdot \mathrm{d}^{-1}$ (Table1). Absolute growth rates were positively correlated with the density of ramets $\left(r_{s}=0.722, p<0.01\right)$. Availability of nutrients ( $\mathrm{N}$ and $\mathrm{P}$ ) in the water and the water and air temperatures did not show significant correlation with absolute growth rates $(\mathrm{p}>0.05)$.

The highest value of relative growth rate $(0.033$ g. $\left.\mathrm{g}^{-1} \cdot \mathrm{d}^{-1}\right)$ was observed in the first 15 days of the experiment (May until June/1994); after this there was a monthly reduction in relative growth. In August the relative growth rates were negative, bottoming out in September/1994 (-0.019 g.g $\left.\mathrm{g}^{-1} \cdot \mathrm{d}^{-1}\right)$. From September to December/1994 the population started to grow again, reaching a relative growth rate of up to $0.031 \mathrm{~g} \cdot \mathrm{g}^{-1} \cdot \mathrm{d}^{-1}$. 
TABLE 1

Air temperature (mean), water temperature, $\mathrm{pH}$, electrical conductivity, total phosphorus, and total nitrogen at the sampling station at Pampulha Reservoir, during the period from May/1994 to April/1995.

\begin{tabular}{|c|c|c|c|c|c|c|}
\hline Months & $\begin{array}{c}\text { Air } \\
\text { temperature } \\
{ }^{\circ} \mathrm{C}\end{array}$ & $\begin{array}{c}\text { Water } \\
\text { temperature } \\
{ }^{\circ} \mathrm{C}\end{array}$ & pH & $\begin{array}{l}\text { Conductivit } \\
\mathrm{y}\left(\boldsymbol{\mu S} . \mathrm{cm}^{-1}\right)\end{array}$ & $\begin{array}{c}\text { Total } \\
\text { phosphorus } \\
\left(\mathbf{m g} \cdot \mathrm{L}^{-1}\right)\end{array}$ & $\begin{array}{c}\text { Total } \\
\text { nitrogen } \\
\left(\mathbf{m g . L ^ { - 1 }}\right)\end{array}$ \\
\hline May & 21.8 & 21.5 & 7.1 & 210.0 & 0.04 & 3.37 \\
\hline June & 19.1 & 22.0 & 7.2 & 234.0 & 0.03 & 1.01 \\
\hline July & 19.1 & 18.0 & 8.3 & 217.0 & 0.08 & 4.63 \\
\hline August & 20.0 & 20.5 & 8.6 & 258.0 & 0.35 & 7.83 \\
\hline September & 22.2 & 26.0 & 7.9 & 301.0 & 1.59 & 7.70 \\
\hline October & 24.0 & 23.0 & 7.7 & 304.0 & 0.35 & 5.14 \\
\hline November & 23.6 & 22.0 & 8.1 & 297.0 & 0.58 & 6.32 \\
\hline December & 24.1 & 29.0 & 8.8 & 283.0 & 0.71 & 8.17 \\
\hline January & 26.0 & 26.0 & 6.9 & 241.0 & 0.53 & 0.85 \\
\hline February & 24.7 & - & - & - & - & - \\
\hline March & 24.0 & 25.0 & 7.2 & 183.0 & 0.47 & 2.11 \\
\hline April & 22.9 & 22.5 & 7.8 & 261.0 & 0.54 & 2.69 \\
\hline
\end{tabular}

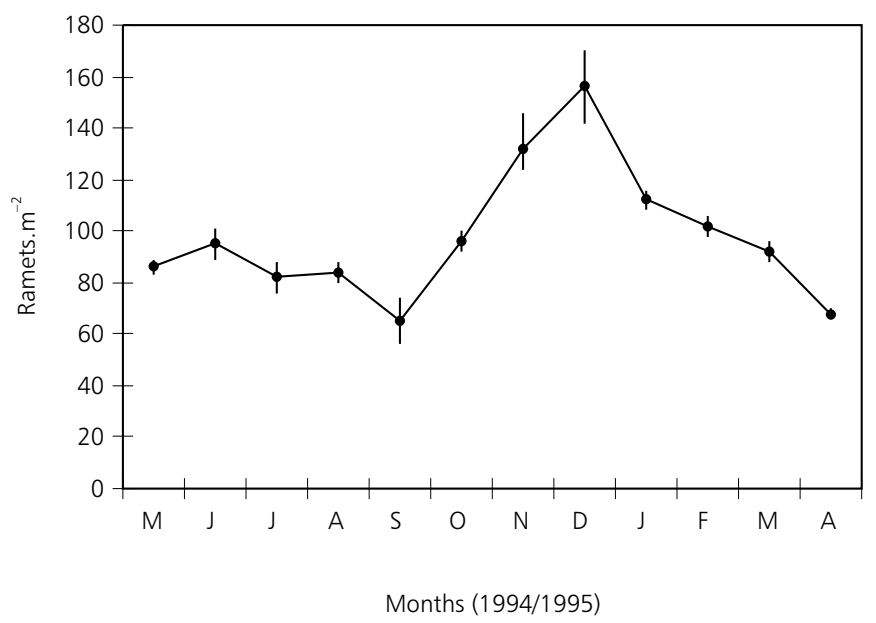

Fig. 1 - Seasonal variation in density of ramets of Eichhornia crassipes (ramets. $\mathrm{m}^{-2}$ ) in Pampulha Reservoir; means and standard errors are represented for each date. 
TABLE 2

Mean biomass (the standard error for each mean is enclosed by parentheses), absolute growth rate (AGR), relative growth rate (RGR), demographic relative growth rate (DRGR) for $E$. crassipes at the sampling station at Pampulha Reservoir, during the period from May/1994 to June/1995.

\begin{tabular}{|c|c|c|c|c|}
\hline \multirow[b]{3}{*}{ Months } & \multicolumn{4}{|c|}{ Methods } \\
\hline & \multicolumn{3}{|c|}{ Traditional } & \multirow{2}{*}{$\begin{array}{c}\text { Demographic } \\
\text { DRGR } \\
\text { “ramets". "ramet".d }\end{array}$} \\
\hline & $\begin{array}{c}\text { Biomass } \\
\text { g DW.m }{ }^{-2}\end{array}$ & $\underset{\left(\mathrm{g} \cdot \mathrm{m}^{-2} \cdot \mathrm{d}^{-1}\right)}{\mathbf{A G R}}$ & $\underset{\left(g^{\prime} \cdot g^{-1} \cdot d^{-1}\right)}{\text { RGR }}$ & \\
\hline May & $96.2(12.5)$ & - & - & - \\
\hline June* & $159.0(27.9)$ & 4.181 & 0,033 & 0.642 \\
\hline June* & $174.4(5.4)$ & 1.027 & 0.006 & 0.011 \\
\hline July & $189.0(18.2)$ & 0.976 & 0.005 & 0.002 \\
\hline August & $169.6(21.1)$ & -0.647 & -0.004 & -0.002 \\
\hline September & $97.2(6.4)$ & -2.413 & -0.019 & -0.004 \\
\hline October & $186.5(28.5)$ & 2.976 & 0.022 & 0.012 \\
\hline November & $402.9(8.0)$ & 7.213 & 0.026 & -0.002 \\
\hline December & $1101.5(86.6)$ & 20.887 & 0.031 & 0.009 \\
\hline January & $2027.0(83.0)$ & 22.167 & 0.015 & -0.003 \\
\hline March & $1776.0(59.3)$ & -5.578 & -0.003 & -0.004 \\
\hline April & $1635.0(119.9)$ & -3.134 & -0.002 & 0.001 \\
\hline June & $1538.2(7.7)$ & -2.150 & -0.001 & - \\
\hline
\end{tabular}

*Two samplings were performed in June, with an interval of 15 days in between.

\section{Demographical approach}

The highest ramet relative growth rate was registered in the first 15 days of observation (June/1994), with a growth of 0.043 ramets. ramet $^{-1}$.day ${ }^{-1}$. After this there was a reduction in growth rate, reaching negative values in August/1994 and September/1994 (DRGR = 0.002 ramets.ramets ${ }^{-1}$. day ${ }^{-1}$ and DRGR $=-0.004$ ramets.ramets ${ }^{-1}$.day ${ }^{-1}$, respectively). In October/ 1994 the population grew at a rate of 0.012 ramets.ramets ${ }^{-1}$.day ${ }^{-1}$. It then suffered another drop until increasing again in December/1994. January and March/1995 howed loss of ramets, i.e., negative values of DRGR; in April/1995 new ramet production began $(\mathrm{DRGR}=0.001$ ramets. ramets $^{-1}$.day ${ }^{-1}$ ) (Table 2).

Fig. 2a shows the flow of ramets, starting with the 142 labeled ramets. After 330 days, they had produced 866 new ones. Of the total, 1028 ramets 609 died and 19 ramets were lost due to herbivore larvae of lepidoptera. The final population comprised 380 ramets.

With this data and the monthly dry weight average per ramet, it was possible to estimate the return of biomass to the aquatic system could be estimated according to the previous equation. On average, plants initially occupying $1 \mathrm{~m}^{2}$, were responsible after 330 days for input of $6628 \mathrm{~g}\left(\mathrm{~s}^{2}=248.42\right)$ of dry mass into the aquatic system, $\mathrm{CI}^{95 \%}=[5632$; 7625] g of DW. In one year, the total input would have been $7331 \mathrm{~g}$ DW.

From the 142 initial ramets 15328 leaves were produced; of these 14193 died during the sampling period. The final ramet population included 1135 functional leaves (Fig. 2b). At the end of 330 days, through a natural process of senescence and leaf death, one square meter of plants was responsible for input of $12796 \mathrm{~g}$ of dry mass into the aquatic system, $\mathrm{CI}^{95 \%}=[11504 ; 14088] \mathrm{g}$ of DW; in one year, this would amount to $14153 \mathrm{~g}$ of DW.

Taking into consideration ramet and leaf loss, $1 \mathrm{~m}^{2}$ of plants loses $19423 \mathrm{~g} \mathrm{DW}$ of its production in a 330 day period. That is, each hectare of water hyacinth can produce an average of 194.3 tons of dry weight in 330 days, roughly 12 tons of which is live matter. Through this data, net production of a single hectare was estimated to be $226.9 \mathrm{t}$ of DW.year ${ }^{-1}$. 

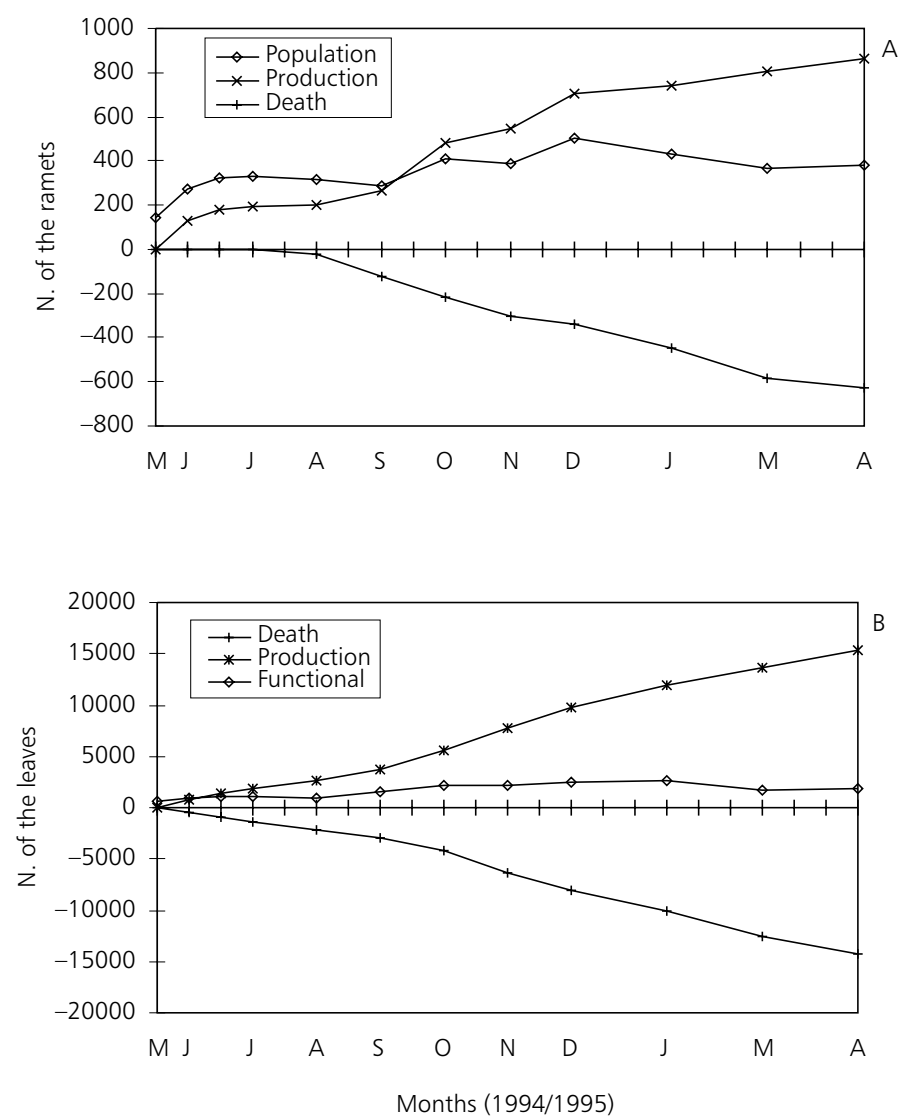

Fig. 2 - Flow of the ramets (A) and leaves (B) of E. crassipes starting with the 142 labeled ramets, from May/1994 to April/ 1995, at the sampling station at Pampulha Reservoir. The values of production and death of the ramets were cumulated. Each interval of the $\mathrm{x}$ axis corresponds to 15 days.

\section{DISCUSSION}

\section{Abiotic factors}

The highest growth rates of E. crassipes were observed in the hottest months of the study period. The low temperatures registered in June, July, and August/1994 and June/1995 may have negatively influenced the growth rate. In these months, average temperatures were below $20^{\circ} \mathrm{C}$, considered inadequate for growth of E. crassipes, which develops fully between 21 and $30^{\circ} \mathrm{C}$ (Kawal $\&$ Grieco, 1983). Variation of the sub-surface level water column temperature probably did not restrict development of the water hyacinth, which withstands temperatures up to $34^{\circ} \mathrm{C}$ (Penfound \& Earle, 1948).

Nutrient concentrations at the Pampulha Reservoir registered during this study are charac- teristic of eutrophic environments. Such factors probably did not inhibit the growth of E. crassipes. High rates for water hyacinth biomass growth and accumulation do not correlate with concentration of phosphorus and nitrogen in the water. Reddy et al. (1989 and 1990) suggest that water analysis is only an indication of environmental nutritional status, and that concentration of nutrients at a certain moment is less important than supply rates. This consideration goes along with the fact that in E. crassipes, old leaves become senescent gradually and decompose while still attached to the plant, allowing time for nutrients translocation for new growth, resulting in the conservation limiting nutrients. Moreover, nutrient liberation by leaf decomposition occurs very near the roots, helping in nutrient recycling by maintaining a continuous supply of phosphorus and nitrogen (Center \& Van, 
1989). In eutrophic environments like the Pampulha Reservoir it is improbable that growth of this species could be restricted by lack of such nutrients.

\section{Biomass production}

The annual net productivity reflects the monthly variations in the absolute growth rate. Under natural conditions, the identification of factors that establish the monthly absolute growth rate is a hard task, since at each census one or another of the environmental factors can be the determinant agent of growth.

In the first months of observation, the positive values of this rate were the result of increased number of ramets (increase in density). This occurred until all available area had been occupied. After this period, ramet average weight increase was the factor determining the high absolute growth rate values. At the end of the experiment, competition processes caused a productivity drop. The highest absolute growth rate of $22.17 \mathrm{~g} \cdot \mathrm{m}^{-2} \cdot \mathrm{d}^{-1}$ is comparable to ones found in the literature, for example $20.0 \mathrm{~g} \cdot \mathrm{m}^{-2} \cdot \mathrm{d}^{-1}$ (Center \& Spencer, 1981).

The primary net productivity of $20.6 \mathrm{t}$ of PS.ha ${ }^{-1}$.year ${ }^{-1}$, measured in this study, is in the intermediate range when compared to the many values registered in the literature. Gaudet (1974), in a revision, showed that E. crassipes in tropical regions exhibits a production that varies from 15 to $44 \mathrm{t}$ of DW.ha ${ }^{-1}$.year ${ }^{-1}$.

Environmental interactions also determine relative growth rate variations. These reached their highest values in June/1994 and December/1994. In our study period, it was estimated that each ton of dry weight in the reservoir had a dry weight daily production around $32 \mathrm{~kg}$. In five months, the relative growth rates were negative; in at least four of these (August and September/1994, March and April/1995), the excessive mortality in comparison with ramet production determined the negative values. In June/1995 the negative values, both for absolute and relative growth rates, possibly reflected weight of the mature ramets. High density, besides generating high mortality, may also result in individual weight loss, since increased selfshading generates an increase in the ratio of respiration to photosynthesis, and decreases net photosynthesis (Moore, 1977).

In clone plants there is a tendency to limit growth of lateral gems when the population is in high density. In E. crassipes this was observed in relation to foliage cover increase. The population presents two phases of ramet production, a faster one before the closing up of the foliage cover, and a slower one following its closing (Geber et al., 1992). Light changes in quantity and quality, after going through foliage cover, and this affects the internal levels of giberilins, producing morphological changes in the leaves and reduction of ramet production rates (Methy \& Roy, 1993). Richards (1982) observed that plants from the center of E. crassipes covers produce less ramets than those at the borders, where ramet production is not supported under dense foliage cover. Density reduction occurs by loss of ramets (probably the youngest), and is a self-regulated mechanism (Center \& Spencer, 1981).

The production of reproductive branches also causes a drop in the ramet production rate, due to the involvement of two meristem types (Watson, 1984). In the present study, the density rise associated with space restriction, which caused increased shading, determined the ramet birth rate drop, since there were very few cases of flowering.

Ramet flow in the population is determined by the vegetative propagation and mortality rates. Leaf turnover is determined by the senescence and leaf production rates. The sum of values representing biomass loss through these two events is an estimate of net production.

Leaf production and mortality rates determined in this study do not indicate a clear pattern. The factors generating the leaf senescence and production rates could not be determined during the study period. In the field, a large group of variables act at the same time, affecting foliage dynamics.

The senescence rate for leaves and branches, besides being a genetic characteristic of a given species, is also a response to environmental stress determined by a wide range of environmental variables. The number of leaves formed by a plant and their longevity decline with density rise. This generates an increase in shading and leaves tend to die faster than those of the same age in favorable conditions of luminosity (White, 1979). Increase in density, when associated with damage provoked by herbivore insects, explains the foliage dynamics of $E$. crassipes. Under these circumstances, there is an increase of leaf production and mortality, raising the foliage turnover rates (Center \& Van, 1989).

In Pampulha Reservoir, the dry mass input into the aquatic system from leaf mortality is approximately twice the ramet input, showing the 
importance of foliage dynamics in determining net primary productivity. Moreover, the phosphorus release due to loss of leaf biomass by $E$. crassipes reached a maximum of $57 \mathrm{mg} \mathrm{P}-\mathrm{PO}_{4} \mathrm{~m}^{-2} \cdot \mathrm{d}^{-1}$, the phosphorus regenerated from ramet reached $33 \mathrm{mg}$ $\mathrm{P}-\mathrm{PO}_{4} \mathrm{~m}^{-2} \cdot \mathrm{d}^{-1}$. Decomposition of water hyacinth biomass is not only a major source of phosphorus for reservoir biota, but also possibly the most important source of regenerated phosphorus during some periods of the year (Pinto-Coelho \& Greco, 1999).

\section{Comparison between the two sampling methods}

Dickerman et al. (1986) highlight the differences between the sampling methods and the frequency of observation for estimating annual liquid production in Typha latifolia; they show the advantage of the use of "Allen's curve", a graphical method that considers the number of plants, the average biomass, and the positive and negative modifications of these two parameters. The demographical approach can be compared with this method, because it considers the same variables. The traditional method is static and a great part of biomass production is not estimated. The demographical method, however, encompasses the variations in production and death of vegetable modules, having the advantage of completely accounting for the growth dynamic and clarifying the processes of initiation and turnover in plants of different sizes and different environments (Waller, 1986).

The comparison of liquid productivity between the two sampling methods used in this study does not seem favorable. In the traditional method, biomass changes are determined in a determined sampling area that remains constant $\left(\mathrm{m}^{2}\right.$ or ha.), whereas in the demographical approach the number of ramets and the occupied area suffer alterations simultaneously. Thus, in the first sampling, one hectare of E. crassipes produces $20.56 \mathrm{t}$ of DW and, in the second, plants that originally occupied one hectare, at the end of a year would produce $232.94 \mathrm{t}$ of DW, but would no longer be occupying one hectare. This difference indicates that more adequate methodologies must be developed and standardized, for the study of macrophytes in tropical environments.
Acknowledgments - We thank A. C. Rietzler for comments and language correction and J. P. Lemos Filho for helpful discussions. We are grateful to L. B. Gazire, L. A. Rocha, and G. Amorim for fieldwork assistance. Financial support was provided by the Ecology, Conservation, and Wildlife Program (UFMG) and CAPES

\section{REFERENCES}

CENTER, T. B. \& VAN, T. K., 1989, Alteration of water hyacinth (Eichhornia crassipes (Mart) Solms) leaf dynamics and phytochemistry by insects reservoirage and plant density. Aquat. Bot., 35: 181-195.

CENTER, T. D. \& SPENCER, N. R., 1981, The phenology and growth of water hyacinth (Eichhornia crassipes (Mart.) Solms) in a eutrophic north-central Florida lake. Aquat. Bot., 10: 1-32.

DICKERMAN, J. A., STEWART, A. \& WETZET, R. G., 1986, Estimates of net annual aboveground production: sensitivity to sampling frequency. Ecology, 67: 650-659.

GAUDET, J. J., 1974, The normal role of vegetation in water. In: D. S. Mitchell (ed.), Aquatic vegetation and its use and control. Unesco, Paris, pp. 24-37.

GEBER, M. A., WATSON, M. A. \& FURNISH, R., 1992, Genetic differences in clonal demography in Eichhornia crassipes. J. Ecol., 80: 329-341.

GIANI, A., 1994, Limnology in Pampulha reservoir: some general observations with emphasis on the phytoplankton community. In: R. M. Pinto-Coelho, A. Giane \& E. VonSperlin (eds.), Ecology and human impact on lakes and reservoirs in Minas Gerais with special reference to future development and management strategies. Belo Horizonte, pp. 141-150.

GOPAL, B., 1987, Water Hyacinth. Elsevier, Oxford, 471p.

GREENBERG, A. E., CLESCERI, L. S. E. \& EATON, A. D., 1992, Standard methods for the examination of water and wastewater. $18^{\text {th }}$ ed., American Public Health Association, Washington, pp. 4/75-4/91.

HOLM, L. G., WELDON, L. W. \& BLACKBURN, R. D., 1969, Aquatic weeds. Science, 166: 699-709.

KAWAL, H. \& GRIECO, V. M., 1983, Utilização do aguapé para tratamento de esgotos domésticos. Estabelecimento de critérios de dimensionamento de lagoas de aguapé e abordagem de alguns problemas operacionais. Rev. DAE, 135: 79-90.

MCGRAW, J. B. \& GARBUTT, K., 1990, Demographic growth analysis. Ecology, 71: 1199-2004.

METHY, M. \& ROY, J., 1993, Morphogenetic changes induced by a low red: far-red ration and their growth consequences in water hyacinth (Eichhornia crassipes). J. Exp. Bot., 44: 1275-1280.

MOORE, P. D., 1977, Restating the self-thinning rule. Nature, 265: 295. 
MURPHY, J. \& RILEY, J. P., 1962, A modified single solution method for the determination of phosphate in natural waters. Analytica Chimica Acta, 27: 31-36.

NAS - National Academy of Sciences, 1981, Making aquatic weeds useful: some perspectives for developing countries. $4^{\text {th }}$ ed., NAS, Washington, 174p.

PENFOUND, W. T. \& EARLE, T. T., 1948, The biology of the water hyacinth. Ecol. Monogr., 18: 447-472.

PINTO-COELHO, R. M. \& GRECO, M. K. B., 1999, The contribution of water hyacinth (Eichhornia crassipes) and zooplankton to the internal cycling of phosphorus in the eutrophic Pampulha Reservoir, Brazil. Hydrobiologia, 411: 115-127.

RADFORD, P. J., 1967, Growth analysis formulae: their use and abuse. Crop. Science, 7: 171-175.

REDDY, K. R., AGAMI, M. \& TUCKER, J. C., 1989. Influence of nitrogen supply rates on growth and nutrient storage by water hyacinth (Eichhornia crassipes) plants. Aquat. Bot., 36: 33-43.

REDDY, K. R., AGAMI, M. \& TUCKER, J. C., 1990, Influence of phosphorus on growth and nutrient storage by water hyacinth (Eichhornia crassipes) plants. Aquat. Bot., 37: 355-365.
RICHARDS, J. H., 1982, Developmental potential of axillary buds of water hyacinth, Eichhornia crassipes SOLMS (Pontederiaceae). Amer. J. Bot., 64: 615-622.

SIEGEL, S., 1975, Estatística não-paramétrica (para as ciências do comportamento). McGraw-Hill, São Paulo, $350 \mathrm{p}$.

WALLER, D. M., 1986, The dynamics of growth and form. In: M. J. Crawley (ed.), Plant ecology. Blackwell Scientific Publications, pp. 291-320.

WATSON, M. A., 1984, Developmental constraints: effect on population growth and patterns of resource allocation in a clonal plant. The Amer. Nat., 123: 411-426.

WESTLAKE, D. J., 1965, Some basic data for investigations of the productivity of aquatic macrophytes. Men. Inst. Ital. Idrobiol., 18: 229-248.

WHITE, J., 1979, The plant as a metapopulation. Ann. Rev. Ecol. Syst., 10: 109-145. 